\title{
Brasília não é a Capital da União
}

\section{UM PROBLEMA JURÍDICO-CONSTITUCIONAL}

ALMEIDA FISCHER

Presidente da Associação Nacional de Escritores. Assessor para Assuntos Legislativos (FIBGE)

Brasília será, de direito, a Capital da República Federativa do Brasil? Eu diria que não. Isto é, que Brasília constitui apenas uma parte da Capital do País. Tanto quanto Sobradinho, Gama, Braslândia, Planaltina, Taguatinga e demais cidades-satélites " são. Isso porque a Constituição de $1967 \mathrm{diz}$, em seu artigo 20: "O Distrito Federal é a Capital da União."

A Emenda Constitucional n? 1, de 17 de outubro de 1969, que passou a viger a partir de 30 dêsse mesmo mês e ano, manteve inalterado o artigo em aprêço, para tristeza dos brasilienses.

Brasilia teria sido, algum dia, a Capital do País? Não o foi, nada obstante a Lei no 2.874 , de 19 de setembro de 1956, "que dispõe sôbre a mudança da Capital Federal, e dá outras providências", estabeleça em seu artigo 33: "É dado o nome de "Brasília" à nova Capital Federal." Acontece, porém, que a Constituição então vigente, a de 1946, já dispunha, no parágrafo 2 \% do seu artigo 1\%, que "O Distrito Federal é a Capital da União." O "Ato das Disposições Constitucionais Transitórias", também de 18 de setembro de 1946, estabelecia, em seu artigo 4ํ, que "A Capital da União será transferida para o Planalto Central do País". Mas não dispunha que a Capital fôsse transferida para Brasília. Dessa forma, a Lei n? 2.874, que deu o nome de Brasília à nova Capital Federal, não tinha e nem tem validade, $v_{\Theta z}$ que contrariava dispositivo expresso da Constituição então em vigor, repetido pela Constituição de 24 de janeiro de 1967.

Em conseqüência, estão errados todos os compêndios, enCiclopédias, cartas e mapas que afirmam ser Brasília a Capital 
do País. Como errados também estavam os livros que davam, antes de 21 de abril de 1960, e a partir de 22 de junho de 1890, 0 Rio de Janeiro como Capital Federal. A Constituição publicada pelo Decreto no 510, dessa data, do Govêrno Provisório da República dos Estados Unidos do Brasil (a primeira Constituição republicana), estabelece, em seu artigo 2!: "Cada uma das antigas províncias formará um Estado, e o antigo Município Neutro constituirá o Distrito Federal, continuando a ser a Capital da União, enquanto outra coisa não deliberar o Congresso."

Na República, o Rio de Janeiro sòmente foi Capital da República, e apenas provisòriamente, de 15 de novembro de 1889 a 21 de junho de 1890. O Decreto $n$ ? 1, que proclamou a República, dispôs, em seu artigo 10: "O território do Município Neutro fica provisòriamente sob a administração imediata do Govêrno Provisório da República e a cidade do Rio de Janeiro constituída, também provisòriamente, sede do Poder Federal." Mas, a primeira Constituição republicana, de 22 de junho de 1890 , cassou-Ihe essa qualidade, transferindo-a para o Distrito Federal.

Dirão alguns que o antigo Distrito Federal e a cidade do Rio de Janeiro eram a mesma coisa. De fato, o território de ambos acabou sendo o mesmo, mas não se pode confundir continente com conteúdo. São coisas diferentes, de diversa conceituação. O Decreto $n$ ? 1 , de 15 novembro de 1889 , talvez o único ato legislativo sôbre o assunto redigido com inteligência, mostra bem a diferença. As capitais de país, tanto quanto as de seus Estados, Departamentos ou Províncias, são sempre uma cidade. Esse decreto dispõe que o antigo Município Neutro fica provisòriamente sob a administração imediata do Govêrno Provisório da República e a cidade do Rio de Janeiro constituída, também provisòriamente, sede do Poder Federal. O Rio de Janeiro da época não ocupava todo o território do antigo Município Neutro, mas apenas parte, situando-se dentro da área que viria a ser a do Distrito Federal. Quando passou a ter Govêrno não imediatamente, mas mediatamente subordinado ao Govêrno $\mathrm{Fe}$ deral, êsse Govêrno era tanto da cidade quanto do Distrito Federal. Tal qual o nôvo Distrito Federal e a cidade de Brasilia, que têm o mesmo Govêrno. A Lei no 4.545, de 10 de dezembro de 1964, mostra bem a diferença entre continente e conteúdo: "Art. 31. O Distrito Federal será dividido em 8 (oito) regiōes administrativas, a saber: Taguatinga, Planaltina, Sobradinho, Braslândia, Gama, Jardim, Paranoá e Brasília." Não está al incluído o Núcleo Bandeirante, hoje também região administrativa do Distrito Federal. A chamada cidade satélite do Guará, inaugurada no ano passado, é mais um prolongamento do setor de 
Indústria e Abastecimento de Brasília do que uma nova região administrativa.

Como se depreende, sem grande esfôrço, do texto dessa lei, Brasília é apenas uma região administrativa do Distrito $\mathrm{Fe}-$ deral, que é, pela Constituição, a Capital da República. Se a Carta Magna fôsse omissa sôbre o assunto, a Lei n’ 2.874 , de 19 de setembro de 1956, que dá o nome de Brasília à nova Capital Federal, seria válida. No entanto, como as Constituições de 46 e 67 são explícitas ao estabelecerem que "O Distrito Federal é a Capital da União", não se pode tergiversar: Brasília não é a Capital da República, mas apenas uma região administrativa da Capital, tanto quanto Sobradinho, Taguatinga, Gama, etc., como já se afirmou neste trabalho. A impropriedade conceitual do texto constitucional torna errados os compêndios, mapas e enciclopédias.

Também o artigo $33^{\circ}$ da Constituição de 1891, que pela primeira vez cuida da transferência da Capital da União para o Planalto Central do País, mostra com clareza a diferença entre continente e conteúdo: "Art. 3 ? Fica pertencendo à União, no Planalto Central da República, uma zona de 14.400 quilômetros quadrados, que será oportunamente demarcada para nela estabelecer-se a futura Capital Federal." A área demarcada acabou sendo bem menor $\left(5.814 \mathrm{Km}^{2}\right.$ e nela, que passou a constituir o nôvo Distrito Federal, devia-se estabelecer a cidade-capital e não todo o seu território transformar-se na Capital do País. o cochilo dos legisladores de 1946 e de 1967 mudou o espírito da Lei Magna de 1891.

As Constituições apresentam, em geral, impropriedades conceituais e vocabulares. Na rápida leitura que fiz de tôdas as nossas Cartas maiores, em busca de textos que se referissem ao assunto principal dêste trabalho, relativo à atual e à antiga Capital da União, encontrei algumas. A Constituição do Império - que sòmente teve uma, a de 25 de março de 1824 - não faz nenhuma referência ao Município Neutro, nem à Capital do País. Mas a lei de 12 de agôsto de 1834, que alterou (sic) essa Constituição, faz alusão ao município da Côrte, ao estabelecer, no final do seu artigo 10: "A autoridade da assembléia legislativa da Província em que estiver a Côrte, não compreenderá a mesma Côrte, nem o seu Município." Então, existiu um Municipio da Côrte, inserido numa Província, que passou mais tarde a ser o Município Neutro. A primeira Constituição republicana, Publicada pelo Decreto no 510 , diz, no parágrafo único do seu artigo 67: "Uma lei do Congresso organizará o Município do Distrito Federal." Aos olhos dos homens de hoje, habituados 
a considerar o distrito parte de Município, parece estranha a expressão organizará o Município do Distrito Federal. O Decreto no 914 , de 23 de outubro de 1890 , que publica a Constituição dos Estados Unidos do Brasil, submetida pelo Govêrno Provisório ao Congresso Constituinte, repete êsse mesmo texto, com uma alteração". . . organizará o Municipio no Distrito Federal". Ainda aí há firmada a diferença entre continente e conteúdo, já referida antes. A alteração do texto foi exatamente para deixar claro que haveria um Município dentro da área do Distrito Federal, Município êsse que seria o da cidade do Rio de Janeiro, Capital da República.

Vou apontar apenas mais dois cochilos dos legisladores, em texto constitucional, vez que o objetivo dêste trabalho não é respigar erros, falhas e equívocos. O artigo 99 da Constituição em vigor diz: "É vedada a acumulação remunerada de cargos e funções públicas, exceto: I - a de juiz com um cargo de professor". Entende-se, pelo texto, que é permitida a acumulação de juiz com um cargo de professor e não, como seria correto, do cargo de juiz com um cargo de professor. 0 artigo 101, da Constituição de 1967 anterior à Emenda Constitucional no 1, estabelece: "Os proventos da aposentadoria serão: I - integrais, quando o funcionário: a) contar trinta e cinco anos de serviço, se do sexo masculino; ou trinta anos de serviço, se do feminino; b) invalidar-se por acidente em serviço, por moléstia profissional, ou doença grave, contagiosa ou incurável, especificada em lei." A colocação enclítica do pronome se, no período "invalidar-se por acidente em serviço...", está errada segundo o Professor Antônio C. Câmara Ribeiro, que discute 0 problema no artigo "A Gramática e a Constituição", publicado no Correio Braziliense, de 23 de janeiro de 1968. Diz o jovem mestre do idioma, em certo trecho dêsse trabalho: "Se o verbo invalidar estivesse no infinito impessoal, então o problema seria outro. Mas ocorre que êle se acha indubitàvelmente no futuro do subjuntivo, e não no infinito impessoal, como pode parecer aos menos avisados. Não se encontrando no infinito impessoal, e sim no futuro do subjuntivo, é de rigor o uso proclítico da variação pronominal se, dada a fôrça atrativa da conjunção subordinativa quando."

Bem andaram os autores da Emenda Constitucional n? 1, de 17 de outubro de 1969, que corrigiram o êrro. $O$ antigo artigo 101 passou a ser o 102, com a seguinte redação: "Os proventos da aposentadoria serão: I - integrais, quando o funcionário: a) contar trinta e cinco anos de serviço, se do sexo masculino, ou 
trinta anos de serviço, se do feminino; ou b) se invalidar por acidente em serviço..."

E claro que os cochilos acontecem, por maior que seja a vigilância dos legisladores. Mas sempre é tempo para saná-los. E preciso que nova emenda constitucional declare que Brasília é a Capital da União, para que realmente o seja. As capitais são sempre cidades que se situam dentro de um Distrito, um Departamento, uma Província. Washington, Capital norte-americana, situa-se no Distrito de Columbia, tão federalizado quanto o nosso Distrito Federal de ontem e de hoje. A Capital da Argentina é a cidade de Buenos Aires, com $200 \mathrm{Km}^{2}$ de superfície que constituem o Distrito Federal, e não a Grande Buenos Aires, que se estende pelo território adjacente da Província de Buenos Aires, cuja Capital é La Plata. A Capital da França é Paris e não - Departamento do Sena, em que se acha inserida. E assim por diante. E preciso que se torne Brasília Capital de fato e de direito do Brasil. Quando mais não seja, pelo menos para que todos os compêndios, enciclopédias e mapas que afirmam que o é não continuem errados. 
